\title{
Clinical Features of Giant Cell Tumor of Bone in Elderly Patients
}

\author{
Hiroyuki Tsuchie ${ }^{1 *}$, Makoto Emori ${ }^{2}$, Hiroyuki Nagasawa' ${ }^{1}$, Yasutaka Murahashi², \\ Emi Mizushima², Junya Shimizu², Toshihiko Yamashita², Naohisa Miyakoshi1 \\ ${ }^{1}$ Department of Orthopedic Surgery, Akita University Graduate School of Medicine, Hondo, Japan \\ ${ }^{2}$ Department of Orthopedic Surgery, Sapporo Medical University School of Medicine, Chūō-ku, Japan \\ Email: *tuchikiti@yahoo.co.jp
}

How to cite this paper: Tsuchie, H., Emori, M., Nagasawa, H., Murahashi, Y., Mizushima, E., Shimizu, J., Yamashita, T. and Miyakoshi, N. (2021) Clinical Features of Giant Cell Tumor of Bone in Elderly Patients. Open Journal of Orthopedics, 11, 257-268. https://doi.org/10.4236/ojo.2021.119024

Received: August 23, 2021

Accepted: September 14, 2021

Published: September 17, 2021

Copyright $\odot 2021$ by author(s) and Scientific Research Publishing Inc. This work is licensed under the Creative Commons Attribution International License (CC BY 4.0).

http://creativecommons.org/licenses/by/4.0/

\begin{abstract}
Background: Giant cell tumor of the bone (GCTB) occurs most often in younger individuals aged between 20 and 40 years. However, it also occurs in a small proportion of elderly people. Therefore, it is necessary to determine the clinical characteristics of GCTB in elderly people, as only few reports have completely examined the characteristics of GCTB in elderly patients. Methods: This retrospective study enrolled 69 patients with benign GCTB. Patients' information on age, sex, anatomical location and size, Campanacci grade, pathological fracture, treatment for primary tumors, local and distant relapse, and outcome was collected. We compared these clinical courses between the younger and older groups. We divided the age groups into three subgroups: $\leq 54$ years and $\geq 55$ years, $\leq 59$ years and $\geq 60$ years, and $\leq 64$ years and $\geq 65$ years. We compared the two groups in each subgroup. In addition, we examined factors affecting local recurrence and distant metastasis. Results: Tumor size was significantly larger in the older group between the two subgroups of 55 and 60 years. Kaplan-Meier curves for local recurrence-free survival and distant metastasis-free survival between the two subgroups of 65 years showed significant differences $(p=0.0183$ and $p=0.0014)$. In the multivariate logistic regression analyses, female sex, curettage-only surgical procedure, and denosumab usage before surgery affected local recurrence. Conclusion: Age is unlikely to affect local recurrence and distant metastases in GCTB patients, but local recurrence and distant metastases may be noted in elderly patients aged $\geq 65$ years with GCTB.
\end{abstract}

\section{Keywords}

Giant Cell Tumor, Bone, Elderly, Local Recurrence 


\section{Introduction}

Giant cell tumor of the bone (GCTB) is a rare mesenchymal tumor. GCTB is classified as a histologically benign lesion composed of mononuclear stromal cells and multinucleated giant cells, and it exhibits ongoing osteoclastic activity. Primary malignant GCTB is rare, accounting for up to $5 \%-10 \%$ of all GCTBs, and most GCTBs are primary benign GCTBs [1]. However, even in primary benign GCTB, local recurrence is likely to occur, and distant metastasis to the lung can occur at a low frequency $(<5 \%)$. Therefore, more attention should be paid to benign GCTB cases.

GCTB occurs most often in younger individuals aged between 20 and 40 years, but it also occurs in middle-aged and older people. Age distribution in GCTB varies across the reports [2]-[8]. Some studies report that there is a rapid decrease in the number of cases among patients aged above the 50s [2] [3] [4], while some studies report that the number of cases among patients aged in the 50s is still relatively large and decreases rapidly from the 60s [5] [6]. In Japan, 1849 GCTB cases have been registered in the registry in 12 years, from 2006 to 2017 , and the proportion of patients is reported to be $11.8 \%$ in those over 50 years old, $8.7 \%$ in those over 55 years old, $6.3 \%$ in those over 60 years old, and $4.5 \%$ in those over 65 years old. Therefore, GCTB occurs at a small but constant rate in middle-aged and elderly people. Thus far, few reports have fully examined the characteristics of GCTB in middle-aged and elderly patients.

The proportion of the elderly population is rapidly increasing in developed countries. According to the United Nations, the most marked increase is expected to occur in Japan [9]. Although $26 \%$ of Japanese citizens were more than 65 years old in 2015, it is said that this will increase to $32 \%$ by 2050 [10]. Although $22 \%$ of the population was over the age of 65 years in Tokyo, Japan in 2015, Akita and Hokkaido, northern regional prefectures, have already shown high rate of the elderly population, at $34 \%$ and $31 \%$, respectively. Therefore, there is a need to fully unravel the clinical characteristics of GCTB in the elderly.

This study aimed to analyze the clinical features of GCTB in elderly patients and identify the age group that is particularly characteristic of this condition.

\section{Materials and Methods}

\subsection{Subjects}

We retrospectively reviewed the medical records of 78 patients with GCTB involving the extremities or trunk and who visited our two institutions between January 1994 and November 2019. We enrolled patients with GCTB who underwent adequate follow-up for GCTB. Patients with malignant GCTB detected at the initial pathological diagnosis and patients with malignancy were excluded from the present study. Finally, 69 consecutive patients with GCTB (35 males and 34 females, with a mean age of 38.0 years, range: 12 - 78 years) were included in this study. Patients' information on age, sex, anatomical location and size of the tumor, Campanacci grade [5], presence of pain, pathological fracture, 
treatment for primary tumors, local and distant relapse, follow-up period, and outcome was collected. We also obtained information about surgical methods such as curettage only, curettage and adjuvant therapies (phenol, absolute ethanol, hot water, and bone cement), and excision. We also investigated the use of denosumab before surgery, which may affect outcomes. In the absence of any events, the date of the last follow-up was considered as the end-point. Local recurrence-free survival was defined as the time during which the patient remained free of local recurrence after resection of the primary tumor. Distant metastasis-free survival was defined as the time during which the patient remained free of metastases after the first consultation. As there were no deaths due to postoperative complications in this study, we defined deaths from GCTB as "died of disease".

In our series, we compared these clinical courses and results between the younger and older groups. We divided the age groups into three subgroups: $\leq 54$ years and $\geq 55$ years, $\leq 59$ years and $\geq 60$ years, and $\leq 64$ years and $\geq 65$ years. We compared the two groups in each subgroup. In addition, we examined factors affecting local recurrence and distant metastasis.

This study was approved by the Institutional Review Board for Clinical Research at Akita University and Sapporo Medical University (approval number: 2477), and informed consent was obtained from all patients.

\subsection{Statistical Analysis}

We compared the clinical courses and results between the younger and older groups and analyzed the factors affecting local recurrence and distant metastasis.

Date of continuous variables was expressed as mean \pm standard deviation. Student's $t$-tests, Welch $t$-tests, and chi-square $\left(\chi^{2}\right)$ tests were used to compare patients' characteristics between the two groups. The curves for local recurrence-free survival and distant metastasis-free survival were constructed using the Kaplan-Meier method, and differences were analyzed using the generalized Wilcoxon test. A Cox proportional hazards model was used to identify the factors associated with local recurrence and distant metastasis. Probability $(p)$ values less than 0.05 were considered significant.

\section{Results}

The mean follow-up period for all patients was $82.3 \pm 77.1$ months (range: 2 486 months). The sites of the primary lesions were the extremities in 63 patients (91.3\%) and axial sites in 6 patients (8.7\%): distal femur in 20 patients, proximal tibia in 18 , proximal fibula in 6 , proximal femur in 4 , distal radius in 4 , distal ulna in 3, proximal humerus in 2, distal tibia in 2, ischium in 2, sternum in 1, proximal ulna in 1, lumbar spine in 1, proximal phalanges of finger in 1, cuboid bone in 1 , and metatarsal bone in 1 . The mean tumor size of the primary lesion was $53.0 \pm 17.3 \mathrm{~mm}$ (range: $11-96 \mathrm{~mm}$ ). The Campanacci grade was grade I in 12 patients, grade II in 28 , grade III in 16 , and unknown in 13. Pain was con- 
firmed in 64 patients (92.8\%), and pathological fractures occurred in 14 patients (20.3\%). Surgical treatment was performed in 64 patients: curettage only in 9 patients, curettage and adjuvant therapies in 47 , and excision in 8 . In adjuvant therapies, phenol was used in 5 patients, absolute ethanol in 8 , hot water in 3 , and bone cement in 36. To treat GCTB, denosumab was administered to 8 patients $(12.5 \%)$ in the preoperative period: 1 patient who underwent curettage only, 5 who underwent curettage and received adjuvant therapies, and 2 underwent excision. A total of 22 patients (34.4\%) developed local recurrence. The mean period until the appearance of local recurrence in patients who underwent surgical treatment was $35.3 \pm 52.6$ months (range: 4 - 240 months). Six patients (8.7\%) developed metastases after the first consultation. The outcomes in all patients were as follows: 59 patients had no evidence of the disease, 7 were alive with the disease, and 3 died owing to the disease. No patients died because of complications during the perioperative period.

Although there were no significant differences in clinical information between the two subgroups of 65 years group, tumor size was significantly larger in elderly patients between the two subgroups of the 55 and 60 years group (Tables 1-3). However, no significant difference was found for other clinical information.

Table 1. Comparison of characteristics between patients aged $\leq 54$ years and those aged $\geq 55$ years.

\begin{tabular}{|c|c|c|c|}
\hline Characteristics & $\leq 54$ & $\geq 55$ & $p$-Value \\
\hline Number & 57 & 12 & \\
\hline Age (years) & $32.4 \pm 10.6$ & $64.6 \pm 5.6$ & - \\
\hline Sex: Male/Female & $30 / 27$ & $5 / 7$ & 0.7092 \\
\hline Location: Extremity/Axial & $52 / 5$ & $11 / 1$ & 0.6068 \\
\hline Size $(\mathrm{mm})$ & $50.2 \pm 15.2$ & $66.3 \pm 21.2$ & 0.0027 \\
\hline \multicolumn{4}{|l|}{ Campanacci grade } \\
\hline Grade I/II/III/Unknown & $11 / 26 / 12 / 8$ & $1 / 2 / 4 / 5$ & 0.2008 \\
\hline Pain: Present/None & $54 / 3$ & $10 / 2$ & 0.4399 \\
\hline Pathological fracture: Present/None & $11 / 46$ & $3 / 9$ & 0.9589 \\
\hline Surgical treatment: Present/None & $54 / 3$ & $10 / 2$ & 0.4399 \\
\hline Surgical methods & & & 0.8747 \\
\hline -Curettage and adjuvant therapy & 39 & 8 & \\
\hline -Excision & 7 & 1 & \\
\hline -Curettage only & 8 & 1 & \\
\hline Denosumab before surgery: Present/None & $5 / 49$ & $3 / 7$ & 0.1932 \\
\hline Local recurrence: Present/None & $19 / 35$ & $3 / 7$ & 0.9639 \\
\hline Time to local recurrence (months) & $38.5 \pm 56.0$ & $15.0 \pm 12.2$ & 0.4860 \\
\hline Distant metastasis - Present/None & $4 / 53$ & $2 / 10$ & 0.6068 \\
\hline Follow-up period (months) & $81.1 \pm 78.7$ & $88.1 \pm 71.8$ & 0.7774 \\
\hline \multicolumn{4}{|l|}{ Outcome at the last follow-up } \\
\hline Alive without disease/Alive with disease/Dead & $50 / 4 / 3$ & $9 / 3 / 0$ & 0.1368 \\
\hline
\end{tabular}


Table 2. Comparison of characteristics between patients aged $\leq 59$ years and those aged $\geq 60$ years.

\begin{tabular}{|c|c|c|c|}
\hline Characteristics & $\leq 59$ years & $\geq 60$ years & $p$-Value \\
\hline Number & 59 & 10 & \\
\hline Age (years) & $33.3 \pm 11.4$ & $66.1 \pm 4.7$ & - \\
\hline Sex: Male/Female & $30 / 29$ & $5 / 5$ & 0.7699 \\
\hline Location: Extremity/Axial & $53 / 6$ & $10 / 0$ & 0.5823 \\
\hline Size $(\mathrm{mm})$ & $51.1 \pm 16.1$ & $64.4 \pm 20.8$ & 0.0236 \\
\hline \multicolumn{4}{|l|}{ Campanacci grade } \\
\hline Grade I/II/III/Unknown & $11 / 27 / 12 / 9$ & $1 / 1 / 4 / 4$ & 0.0830 \\
\hline Pain: Present/None & $56 / 3$ & $8 / 2$ & 0.3064 \\
\hline Pathological fracture: Present/None & $11 / 48$ & $3 / 7$ & 0.6888 \\
\hline Surgical treatment: Present/None & $55 / 4$ & $9 / 1$ & 0.7670 \\
\hline Surgical methods & & & 0.9475 \\
\hline -Curettage and adjuvant therapy & 40 & 7 & \\
\hline -Excision & 7 & 1 & \\
\hline -Curettage only & 8 & 1 & \\
\hline Denosumab before surgery: Present/None & $5 / 50$ & $3 / 6$ & 0.1349 \\
\hline Local recurrence: Present/None & $19 / 36$ & $3 / 6$ & 0.7584 \\
\hline Time to local recurrence (months) & $38.5 \pm 56.0$ & $15.0 \pm 12.2$ & 0.4860 \\
\hline Distant metastasis: Present/None & $4 / 55$ & $2 / 8$ & 0.4442 \\
\hline Follow-up period (months) & $83.1 \pm 78.2$ & $77.8 \pm 73.7$ & 0.8443 \\
\hline \multicolumn{4}{|l|}{ Outcome at the last follow-up } \\
\hline Alive without disease/Alive with disease/Dead & $51 / 5 / 3$ & $8 / 2 / 0$ & 0.4340 \\
\hline
\end{tabular}

Values are expressed as the number and proportion of patients or mean \pm standard deviation (SD) with range.

Although there were no significant differences in Kaplan-Meier curves for local recurrence-free survival between the two subgroups of 55 and 60 years, Kaplan-Meier curves for local recurrence-free survival between the two subgroup of the 65 years group showed significant difference $(p=0.0183)$, and local recurrence was likely to occur in elderly patients (Figure 1). Similarly, Kaplan-Meier curves for distant metastasis-free survival showed significantly poor prognosis in elderly patients between the two subgroups of the 65 years group ( $p=$ 0.0014) (Figure 2). In the univariate and multivariate Cox regression analyses, female sex, curettage-only surgical procedure, and denosumab usage before surgery affected local recurrence (Table 4). However, there were no evident factors affecting distant metastasis.

\section{Discussion}

In our analysis, age was not an apparent poor prognostic factor for local recurrence and distant metastases in multivariate analysis. However, Kaplan-Meier curves showed a significantly higher risk of local recurrence and distant metastasis 
Table 3. Comparison of characteristics between patients aged $\leq 64$ years and those aged $\geq 65$ years.

\begin{tabular}{|c|c|c|c|}
\hline Characteristics & $\leq 64$ years & $\geq 65$ years & $p$-Value \\
\hline Number & 63 & 6 & \\
\hline Age (years) & $35.1 \pm 13.1$ & $68.5 \pm 4.8$ & - \\
\hline Sex: Male/Female & $32 / 31$ & $3 / 3$ & 0.6964 \\
\hline Location: Extremity/Axial & $57 / 6$ & $6 / 0$ & 1.0000 \\
\hline Size $(\mathrm{mm})$ & $52.8 \pm 17.2$ & $55.8 \pm 20.7$ & 0.6815 \\
\hline \multicolumn{4}{|l|}{ Campanacci grade } \\
\hline Grade I/II/III/Unknown & $11 / 28 / 14 / 10$ & $1 / 0 / 2 / 3$ & 0.1823 \\
\hline Pain: Present/None & $59 / 4$ & $5 / 1$ & 0.9144 \\
\hline Pathological fracture: Present/None & $13 / 50$ & $1 / 5$ & 0.7640 \\
\hline Surgical treatment: Present/None & $59 / 4$ & $5 / 1$ & 0.9144 \\
\hline Surgical methods & & & 0.6552 \\
\hline -Curettage and adjuvant therapy & 43 & 4 & \\
\hline -Excision & 8 & 0 & \\
\hline -Curettage only & 8 & 1 & \\
\hline Denosumab before surgery: Present/None & $7 / 52$ & $1 / 4$ & 0.8603 \\
\hline Local recurrence: Present/None & $19 / 40$ & $3 / 2$ & 0.4436 \\
\hline Time to local recurrence (months) & $38.5 \pm 56.0$ & $15.0 \pm 12.2$ & 0.4860 \\
\hline Distant metastasis: Present/None & $4 / 59$ & $2 / 4$ & 0.1380 \\
\hline Follow-up period (months) & $83.6 \pm 68.7$ & $68.7 \pm 76.5$ & 0.6534 \\
\hline \multicolumn{4}{|l|}{ Outcome at the last follow-up } \\
\hline Alive without disease/Alive with disease/Dead & $55 / 5 / 3$ & $4 / 2 / 0$ & 0.1326 \\
\hline
\end{tabular}

Values are expressed as the number and proportion of patients or mean \pm standard deviation (SD) with range.

in GCTB patients aged 65 years and older. However, few previous reports have shown that age affects local recurrence or distant metastases [10]-[18]. Most reports have shown that age is not a risk factor [10]-[15]. Moreover, a study reported a lower risk of local recurrence in GCTB patients aged 51 years and older [16]. However, some reports showed that older age may have adverse effects in patients with GCTB [17] [18]. Amelio et al. analyzed 337 GCTB patients and reported a higher mortality rate in older age, especially over 55 years old [17]. Lin et al. examined 334 GCTB patients and showed that the Enneking stage was advanced in GCTB patients aged 40 years and older [18]. Although there are various reports on whether age is a risk factor, as described above, the criteria for old age are different in each study. Therefore, in our study, we divided age into three groups, namely, 55, 60, and 65 years old, and we analyzed each of them. Then, it was shown that the course of local recurrence and distant metastasis was rapidly poor when the GCTB patients of the 65 years group were divided into two subgroups, which had never been analyzed in the past. Considering the results of the current study that age was not a risk factor in multivariate analysis, it 
Table 4. Results of univariate and multivariate analyses of factors affecting local recurrence-free survival and distant metastasis-free survival.

\begin{tabular}{|c|c|c|c|c|c|c|}
\hline \multirow{2}{*}{ Variables } & \multicolumn{3}{|c|}{ Univariate } & \multicolumn{3}{|c|}{ Multivariate } \\
\hline & OR & $95 \%$ CI & $p$-Value & OR & $95 \%$ CI & $p$-Value \\
\hline \multicolumn{7}{|l|}{ Local recurrence } \\
\hline Age & 0.992 & $0.963-1.021$ & 0.5800 & & & \\
\hline Sex: Female & 2.707 & $1.042-7.031$ & 0.0408 & 2.770 & $1.036-7.406$ & 0.0423 \\
\hline Size & 0.990 & $0.960-1.022$ & 0.5542 & & & \\
\hline Campanacci grade & 1.554 & $0.756-3.193$ & 0.2306 & & & \\
\hline Symptom: Pain & 1.056 & $0.141-7.906$ & 0.9575 & & & \\
\hline Pathological fracture & 1.887 & $0.724-4.920$ & 0.1940 & & & \\
\hline Surgical methods: Curettage only & 3.741 & $1.430-9.789$ & 0.0072 & 3.686 & $1.322-10.277$ & 0.0126 \\
\hline Denosumab before surgery & 3.481 & $1.124-10.780$ & 0.0306 & 5.445 & $1.639-18.084$ & 0.0056 \\
\hline \multicolumn{7}{|l|}{ Distant metastasis } \\
\hline Age & 1.022 & $0.970-1.077$ & 0.4054 & & & \\
\hline Sex: Female & 0.952 & $0.192-4.729$ & 0.9524 & & & \\
\hline Location: axial & 4.188 & $0.720-24.352$ & 0.1108 & & & \\
\hline Size & 0.971 & $0.922-1.022$ & 0.2614 & & & \\
\hline Campanacci grade & 1.487 & $0.371-5.961$ & 0.5752 & & & \\
\hline Pathological fracture & 1.065 & $0.119-9.546$ & 0.9549 & & & \\
\hline Surgical treatment & 0.208 & $0.037-1.164$ & 0.0743 & & & \\
\hline Denosumab before surgery & 5.393 & $0.482-60.354$ & 0.1715 & & & \\
\hline Local recurrence & 2.287 & $0.379-13.816$ & 0.3674 & & & \\
\hline
\end{tabular}

OR: odds ratio, $95 \%$ CI: $95 \%$ confidence interval.

was considered that the clinical course of local recurrence and distant metastasis did not worsen as the age increased, but the prognosis may suddenly worsen after a certain age.

The most commonly reported risk factors for local recurrence are non-adjuvant curettage surgery and extraosseous tumor progression (high grade of Campanacci classification) [5] [12] [19] [20] [21]. In our study, curettage without adjuvant therapy was cited as one of the risk factors for local recurrence, and the result was similar to those in the past. Various other factors, such as the presence of distant metastases at the first visit and development of the primary tumor in the proximal tibia have been reported in the past as risk factors [22] [23] [24]. In our study, female sex was also observed to be a risk factor for local recurrence. However, some reports show different results for these factors [16] [25] [26], and it is difficult to say that there is sufficient consensus. Distant metastasis has the same recognition as that for local recurrence. It is well reported that the risk of distant metastasis is high when the number of local recurrences is frequent [13] [14] [15]. However, the site, bearing time, and size of the tumor have also been reported as risk factors for distant metastasis [13] [14] [27]. For example, regarding the site of tumor occurrence, while the distal radius is reported to be a risk factor, the bone around the knee is also reported as a risk factor [27] [28], and it is unlikely that there is sufficient consensus on these 

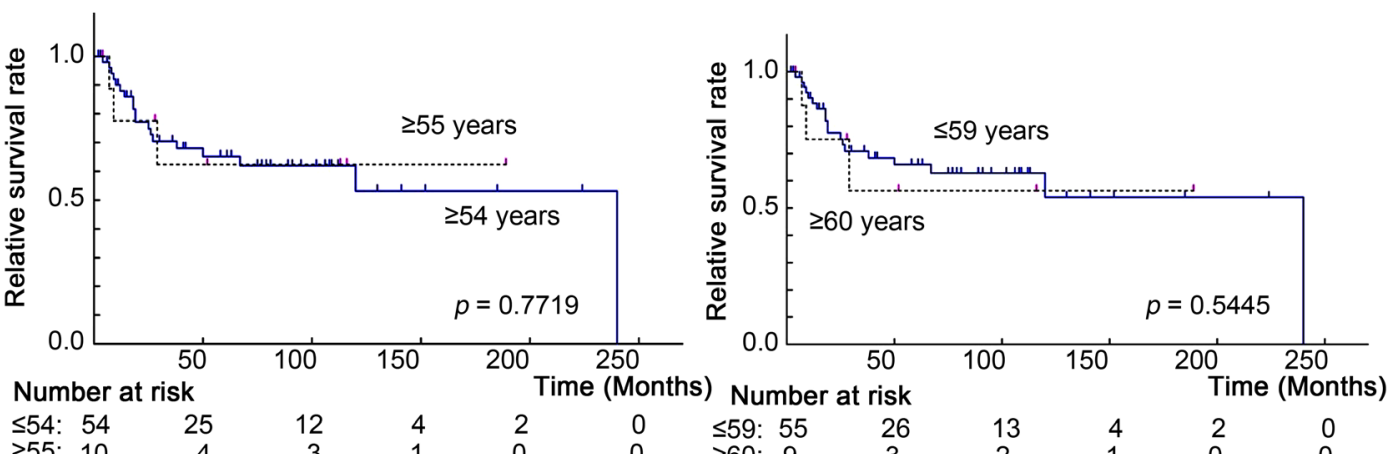

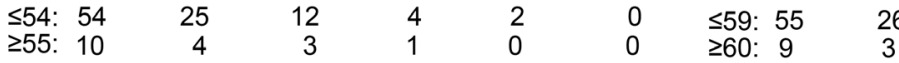

(a)

(b)

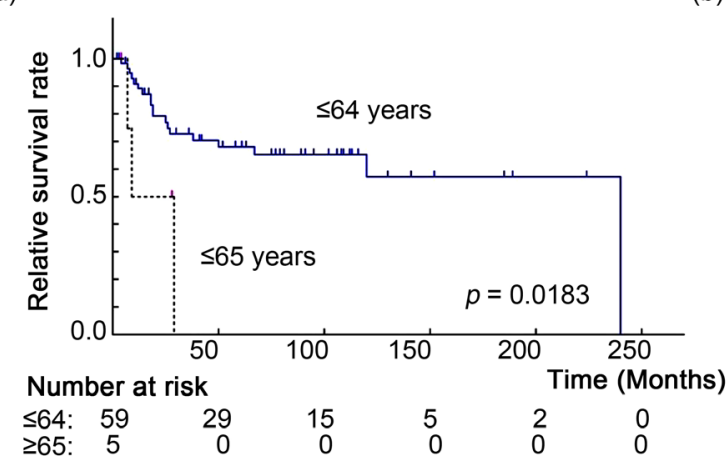

(c)

Figure 1. Kaplan-Meier local recurrence-free survival curves between each 2 groups divided into 55 (a), 60 (b), and 65 (c) years. A significant difference was shown between the 2 groups divided into 65 years $(p=0.0183)$.
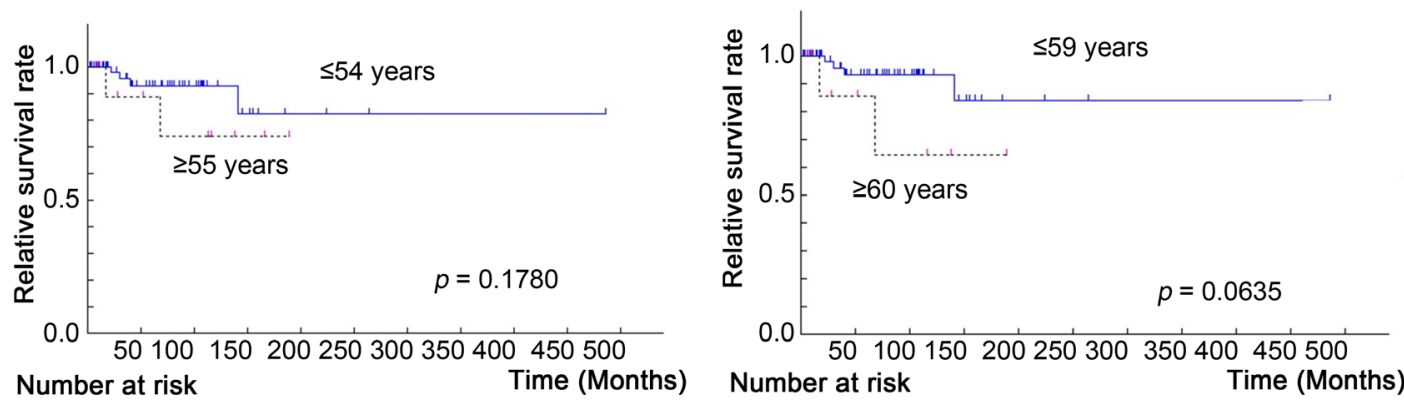

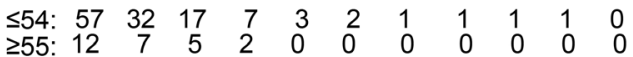

(a)

(b)
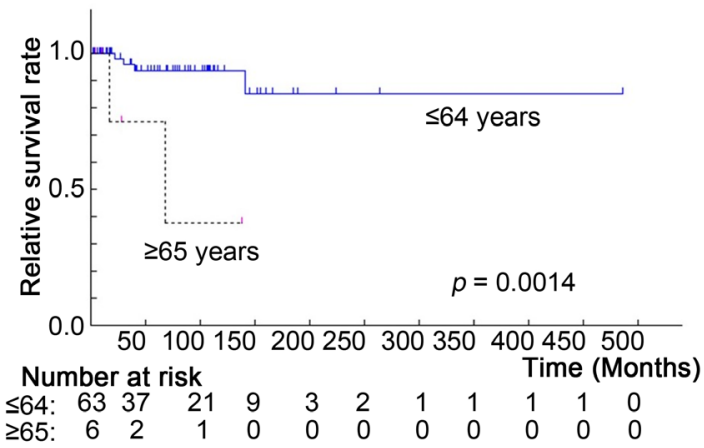

(c)

Figure 2. Kaplan-Meier distant metastasis-free survival curves between each 2 groups divided into 55 (a), 60 (b), and 65 (c) years. A significant difference was shown between the 2 groups divided into 65 years $(p=0.0014)$. 
proposed risk factors.

Denosumab is a fully human monoclonal antibody that specifically binds to RANK ligand and inhibits its action. Because GCTB produces and is dependent on RANK ligand for growth, denosumab can be expected to suppress the increase of GCTB. However, it has recently been reported that the use of denosumab before curettage surgery increases the local recurrence rate [29] [30], and we also reported the preoperative use of denosumab as a risk factor for local recurrence. Although the use of denosumab in unresectable cases is a good indication for GCTB, it should not be used in patients in whom curettage surgery is assumed.

In this study, the local recurrence rate was $34.4 \%$ and the distant metastasis rate was $8.7 \%$, both of which were higher than those reported in recent studies [10] [12]-[19] [24]. In the 64 GCTB patients who received surgical treatment, 8 used denosumab preoperatively, 9 underwent curettage surgery without adjuvant therapy, and a total of 17 patients received treatment with a high risk of local recurrence. This is considered to have greatly affected the high local recurrence rate and the incidence of distant metastasis.

The strength of the present study is that this is the first study to examine in detail the characteristics of GCTB in middle-aged and older patients grouped by age and to show the potential risks in elderly patients with GCTB. However, several limitations of our study should be mentioned. First, the number of GCTB cases is small, especially in elderly patients. There were only 6 GCTB patients over the age of 65 years. Several factors may have led to biases such as Campanacci classification, tumor size, and tumor location. Second, there are various surgical methods, and various adjuvant therapies are combined with curettage surgery. Because it was difficult to compare these contents in detail, we could divide them only into the curettage only group or the curettage with adjuvant therapy and excision group. The number of patients is limited, and it is difficult to strictly comply with the criteria for target patients.

\section{Conclusion}

In conclusion, the present study showed some clinical features of GCTB in elderly patients. Age is unlikely to affect local recurrence and distant metastases in GCTB patients, but local recurrence and distant metastases may be noted in elderly patients aged 65 years and older.

\section{Conflicts of Interest}

The authors declare no conflicts of interest regarding the publication of this paper.

\section{References}

[1] Bertoni, F., Bacchini, P. and Staals, E.L. (2003) Malignancy in Giant Cell Tumor of Bone. Cancer, 97, 2520-2529. https://doi.org/10.1002/cncr.11359 
[2] Dahlin, D.C. (1985) Caldwell Lecture. Giant Cell Tumor of Bone: Highlights of 407 Cases. American Journal of Roentgenology, 144, 955-960. https://doi.org/10.2214/ajr.144.5.955

[3] Werner, M. (2006) Giant Cell Tumour of Bone: Morphological, Biological and Histogenetical Aspects. International Orthopaedics, 30, 484-489. https://doi.org/10.1007/s00264-006-0215-7

[4] Baena-Ocampo, Ldel, C., Ramirez-Perez, E., Linares-Gonzalez, L.M. and Delgado-Chavez, R. (2009) Epidemiology of Bone Tumors in Mexico City: Retrospective Clinicopathologic Study of 566 Patients at a Referral Institution. Annals of Diagnostic Pathology, 13, 16-21. https://doi.org/10.1016/j.anndiagpath.2008.07.005

[5] Campanacci, M., Baldini, N., Boriani, S. and Sudanese, A. (1987) Giant-Cell Tumor of Bone. The Journal of Bone \& Joint Surgery, 69, 106-114. https://doi.org/10.2106/00004623-198769010-00018

[6] Liede, A., Bach, B.A., Stryker, S., Hernandez, R.K., Sobocki, P., Bennett, B. and Wong, S.S. (2014) Regional Variation and Challenges in Estimating the Incidence of Giant Cell Tumor of Bone. Journal of Bone and Joint Surgery, 96, 1999-2007. https://doi.org/10.2106/JBJS.N.00367

[7] Larsson, S.E., Lorentzon, R. and Boquist, L. (1975) Giant-cell Tumor of Bone. A Demographic, Clinical, and Histopathological Study of All Cases Recorded in the Swedish Cancer Registry for the Years 1958 through 1968. Journal of Bone \& Joint Surgery, 57, 167-173. https://doi.org/10.2106/00004623-197557020-00007

[8] Niu, X., Xu, H., Inwards, C.Y., Li, Y., Ding, Y., Letson, G.D. and Bui, M.M. (2015) Primary Bone Tumors: Epidemiologic Comparison of 9200 Patients Treated at Beijing Ji Shui Tan Hospital, Beijing, China, with 10165 Patients at Mayo Clinic, Rochester, Minnesota. Archives of Pathology \& Laboratory Medicine, 139, 1149-1155. https://doi.org/10.5858/arpa.2014-0432-OA

[9] Japan Orthopaedic Association Muscloskeletal Tumor Committee/National Cancer Center (2017) Bone and Soft Tissue Tumor Registry in Japan.

[10] Broehm, C.J., Inwards, C.Y., Al-Ibraheemi, A., Wenger, D.E., Jenkins, S.M., Jin, L., Oliveira, A.M., Zreik, R.T., Carter, J.M., Boland, J.M. and Fritchie, K.J. (2018) Giant Cell Tumor of Bone in Patients 55 Years and Older: A Study of 34 Patients. American Journal of Clinical Pathology, 149, 222-233. https://doi.org/10.1093/ajcp/aqx155

[11] McCarthy, E.F. and Weber, K.L. (2009) Giant Cell Tumor of Bone in Elderly Patients: A Study of Ten Patients. Iowa Orthopedic Journal, 29, 79-82.

[12] Hasan, O., Ali, M., Mustafa, M., Ali, A. and Umer, M. (2019) Treatment and Recurrence of Giant Cell Tumors of Bone-A Retrospective Cohort from a Developing Country. Annals of Medicine and Surgery, 48, 29-34. https://doi.org/10.1016/j.amsu.2019.10.010

[13] Yayan, J. (2019) Increased Risk of Lung Metastases in Patients with Giant Cell Bone Tumors: A Systematic Review. In: Pokorski, M., Ed., Advances in Biomedicine, Vol. 1176, Springer, Cham, 1-17. https://doi.org/10.1007/5584_2019 372

[14] Wang, B., Chen, W., Xie, X., Tu, J., Huang, G., Zou, C., Yin, J., Wen, L. and Shen, J. (2017) Development and Validation of a Prognostic Index to Predict Pulmonary Metastasis of Giant Cell Tumor of Bone. Oncotarget, 8, 108054-108063. https://doi.org/10.18632/oncotarget.22478

[15] Chan, C.M., Adler, Z., Reith, J.D. and Gibbs Jr., C.P. (2015)) Risk Factors for Pulmonary Metastases from Giant Cell Tumor of Bone. Journal of Bone and Joint Surgery, 97, 420-428. https://doi.org/10.2106/JBJS.N.00678 
[16] Klenke, F.M., Wenger, D.E., Inwards, C.Y., Rose, P.S. and Sim, F.H. (2011) Giant Cell Tumor of Bone: Risk Factors for Recurrence. Clinical Orthopaedics and Related Research, 469, 591-599. https://doi.org/10.1007/s11999-010-1501-7

[17] Amelio, J.M., Rockberg, J., Hernandez, R.K., Sobocki, P., Stryker, S., Bach, B.A., Engellau, J. and Liede, A. (2016) Population-Based Study of Giant Cell Tumor of Bone in Sweden (1983-2011). Cancer Epidemiology, 42, 82-89.

https://doi.org/10.1016/j.canep.2016.03.014

[18] Lin, F., Hu, Y., Zhao, L., Zhang, H., Yu, X., Wang, Z., Ye, Z., Wu, S., Guo, S., Zhang, G. and Wang, J. (2016) The Epidemiological and Clinical Features of Primary Giant Cell Tumor around the Knee: A Report from the Multicenter Retrospective Study in China. Journal of Bone Oncology, 5, 38-42.

https://doi.org/10.1016/j.jbo.2016.02.001

[19] Balke, M., Schremper, L., Gebert, C., Ahrens, H., Streitbuerger, A., Koehler, G., Hardes, J. and Gosheger, G. (2008) Giant Cell Tumor of Bone: Treatment and Outcome of 214 Cases. Journal of Cancer Research and Clinical Oncology, 134, 969-978. https://doi.org/10.1007/s00432-008-0370-x

[20] Blackley, H.R., Wunder, J.S., Davis, A.M., White, L.M., Kandel, R. and Bell, R.S. (1999) Treatment of Giant-Cell Tumors of Long Bones with Curettage and BoneGrafting. Journal of Bone \& Joint Surgery, 81, 811-820. https://doi.org/10.2106/00004623-199906000-00008

[21] Goldenberg, R.R., Campbell, C.J. and Bonfiglio, M. (1970) Giant-Cell Tumor of Bone. An Analysis of Two Hundred and Eighteen Cases. Journal of Bone \& Joint Surgery, 52, 619-664. https://doi.org/10.2106/00004623-197052040-00001

[22] Osaka, S., Toriyama, M., Taira, K., Sano, S. and Saotome, K. (1997) Analysis of Giant Cell Tumor of Bone with Pulmonary Metastases. Clinical Orthopaedics and Related Research, 335, 253-261. https://doi.org/10.1097/00003086-199702000-00026

[23] Rock, M.G., Pritchard, D.J. and Unni, K.K. (1984) Metastases from Histologically Benign Giant-Cell Tumor of Bone. Journal of Bone \& Joint Surgery, 66, 269-274. https://doi.org/10.2106/00004623-198466020-00014

[24] Siddiqui, M.A., Seng, C. and Tan, M.H. (2014) Risk Factors for Recurrence of Giant Cell Tumours of Bone. Journal of Orthopaedic Surgery, 22, 108-110. https://doi.org/10.1177\%2F230949901402200127

[25] Arbeitsgemeinschaft, Knochentumoren, Becker, W.T., Dohle, J., Bernd, L., Braun, A., Cserhati, M., Enderle, A., Hovy, L., Matejovsky, Z., Szendroi, M., Trieb, K. and Tunn, P.U. (2008) Local Recurrence of Giant Cell Tumor of Bone after Intralesional Treatment with and without Adjuvant Therapy. Journal of Bone \& Joint Surgery, 90, 1060-1067. https://doi.org/10.2106/JBJS.D.02771

[26] van, der, Heijden, L., van, de, Sande, M.A. and Dijkstra, P.D. (2012) Soft Tissue Extension Increases the Risk of Local Recurrence after Curettage with Adjuvants for Giant-Cell Tumor of the Long Bones. Acta Orthopaedica, 83, 401-405. https://doi.org/10.3109/17453674.2012.711193

[27] Siebenrock, K.A., Unni, K.K. and Rock, M.G. (1998) Giant-Cell Tumour of Bone Metastasising to the Lungs. A Long-Term Follow-Up. The Journal of Bone and Joint Surgery, 80-B, 43-47. https://doi.org/10.1302/0301-620X.80B1.0800043

[28] Dominkus, M., Ruggieri, P., Bertoni, F., Briccoli, A., Picci, P., Rocca, M. and Mercuri, M. (2006) Histologically Verified Lung Metastases in Benign Giant Cell Tumours-14 Cases from a Single Institution. International Orthopaedics, 30, 499-504. https://doi.org/10.1007/s00264-006-0204-x

[29] Errani, C., Tsukamoto, S., Leone, G., Righi, A., Akahane, M., Tanaka, Y. and Dona- 
ti, D.M. (2018) Denosumab May Increase the Risk of Local Recurrence in Patients with Giant-Cell Tumor of Bone Treated with Curettage. Journal of Bone and Joint Surgery, 100, 496-504. https://doi.org/10.2106/JB/S.17.00057

[30] Tsukamoto, S., Tanaka, Y., Mavrogenis, A.F., Kido, A., Kawaguchi, M. and Errani, C. (2020) Is Treatment with Denosumab Associated with Local Recurrence in Patients with Giant Cell Tumor of Bone Treated with Curettage? A Systematic Review. Clinical Orthopaedics and Related Research, 478, 1076-1085.

https://doi.org/10.1097/CORR.0000000000001074 